\title{
Low Grade Mucoepidermoid Breast
}

\section{Carcinoma}

National Cancer Institute

\section{Source}

National Cancer Institute. Low Grade Mucoepidermoid Breast Carcinoma. NCI

Thesaurus. Code C5168.

A slow growing mucoepidermoid carcinoma characterized by the presence of keratinization in the neoplastic squamous cells and lumina formation by glandular neoplastic cells. Complete excision may be curative. 